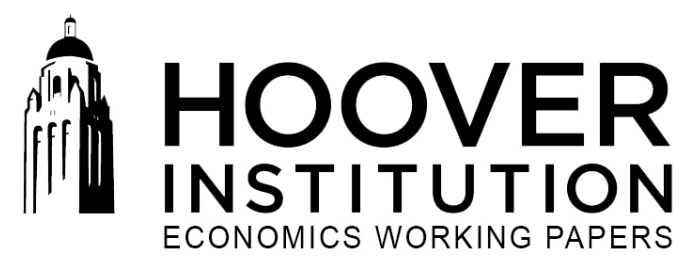

\title{
A New Structure for U.S. Federal Debt
}

\author{
John H. Cochrane* \\ Economics Working Paper 15108 \\ HOOVER INSTITUTION \\ 434 GALVEZ MALL \\ STANFORD UNIVERSITY \\ STANFORD, CA 94305-6010
}

May 15, 2015

This paper proposes a new structure for U.S. Federal debt. It argues that all debt should be perpetual, paying coupons forever with no principal payment. The paper introduces six financing options and argues for their creation in order to protect against future fiscal or monetary shocks.

*Hoover Institution, NBER, and Cato Institute. I thank Effi Benmelech, Michael Boskin, John Campbell, Sebastian Di Tella, Darrell Duffie, Niall Ferguson, Bob Hall, Derek Kaufman, Josh Rauh, Larry Summers, John Taylor, Luis Viceira, and participants at the U.S. Treasury 2014 Roundtable on Treasury Markets and Debt Management for many helpful comments.

The Hoover Institution Economics Working Paper Series allows authors to distribute research for discussion and comment among other researchers. Working papers reflect the views of the author and not the views of the Hoover Institution. 


\title{
A New Structure for U. S. Federal Debt
}

\author{
John H. Cochrane*
}

${ }^{*}$ Hoover Institution, University of Chicago Booth School of Business, NBER, and Cato Institute. http://faculty.chicagobooth.edu/john.cochrane/. I thank Effi Benmelech, Michael Boskin, John Campbell, Sebastian Di Tella, Darrell Duffie, Niall Ferguson, Bob Hall, Derek Kaufman, Josh Rauh, Larry Summers, John Taylor, Luis Viceira, and participants at the U. S. Treasury 2014 Roundtable on Treasury Markets and Debt Management for many helpful comments. 


\section{Introduction and overview}

What securities should the U. S. Treasury offer? Traditionally, the Treasury has offered longterm coupon bonds, short-term notes and bills, and retail savings bonds, securities not much changed since the $19^{\text {th }}$ century.

But Treasury debt has taken on new and different functions in our financial system, and in monetary and fiscal policy. Short-term debt has become a form of interest-paying electronic money, and all Treasury debt is widely used as liquid collateral. Underlying these changes, financial, communications, and information technology have changed rapidly. The securities that financed borrowing and served financial markets decades ago are not obviously optimal today.

Furthermore, though we are currently experiencing a quiet time of great demand for U.S. Treasury debt, a strong dollar, and low interest rates, we also live in a time of large debt and doubts about the long-term ability of the U.S. and other governments to pay those debts. Unexpected events such as a war, recession or a new financial crisis will put pressure on the U.S. budget and borrowing capacity. An improved structure of Treasury debt can contribute to the U.S.' ability to meet these challenges.

Finally, economic understanding of government debt has advanced in the last several decades, both through advances in economic theory, and via the experience of policy innovations and events around the world.

The Treasury has already pursued several innovations, including inflation-protected securities (TIPS) and floating-rate notes. One can imagine many more similar innovations, and a more comprehensive approach.

For all these reasons, a ground-up reexamination of the structure of Treasury debt is important and timely.

\subsection{Goals}

The right structure of Treasury debt follows from the goals one sets for it as well as a recognition of the changed environment.

The first, traditional, goal of debt management is to fund deficits at lowest long-run cost to the taxpayer. ${ }^{1}$ Moreover, in times of war or economic emergency such as the recent financial crisis, the U.S. needs the ability to borrow additional amounts quickly and cheaply.

\footnotetext{
${ }^{1}$ See p. 5 of http://www.publicdebt.treas.gov/whatwedo/bpdstrategicplan09-14.pdf.
} 
A second goal is to provide liquid and otherwise useful securities that the market desires, securities that enhance financial and macroeconomic stability, and securities that the Government has a natural advantage in producing.

To some extent, this goal is a consequence of the first. If the U. S. can issue securities that are more liquid, more useful, or otherwise more valuable to investors, then the U. S. will be able to borrow larger amounts at lower rates.

But this second goal has a direct policy purpose as well. U.S. Treasury debt has unique financial features and uses, deriving ultimately from the fact that U.S. debt is uniquely liquid and much less likely to default than any private debt. Providing the right structure and quantity of Treasury debt therefore has an economic policy benefit unrelated to financing deficits. By analogy, the government profits by printing money. But monetary policy is not devoted to maximizing seignorage revenue. More generally, the government provides public goods that it has a unique ability to produce, such as roads, defense, measurement standards, and currency.

A third goal is to manage the risks of interest rate increases and other adverse events to the U. S. budget and to the economy. For example, if interest rates rise five percentage points back to historical norms, then Congress must either raise taxes, lower spending, or borrow an additional $\$ 650$ billion per year, once the $\$ 13$ trillion of publicly held debt rolls over. The longer the maturity of outstanding debt, the longer that day of fiscal reckoning is put off. But issuing longterm debt may be more expensive. It's not a trivial problem, as the analysis in Chapter 1 of this volume attests. The debt can be structured to allow the Treasury to manage risks induced by interest rates, inflation, and other factors more quickly and flexibly.

Macro-economic stabilization is a new fourth goal. For example, the Federal Reserve's quantitative easing program essentially shortened the maturity of Treasury debt in private hands, and swapped mortgage debt for government debt, in efforts to stimulate the economy. Whether or not one approves of that decision, it is useful to ask if there is a better set of tools for managing Treasury debt as economic policy.

\subsection{The securities}

With these circumstances and goals in mind, I propose that Treasury debt should comprise the following securities. Later sections explain how each type of debt works in detail and meet common objections.

\section{Fixed-value, floating-rate debt}

This debt has a fixed value of $\$ 1.00$, and pays a floating overnight interest rate. It is electronically transferable, and sold in arbitrary denominations. Such debt looks to an investor 
like a money-market fund, or interest-paying reserves at the Fed. The Treasury allows investors to freely exchange this debt for bank reserves at the Fed, and thus to bank accounts and to cash.

Fixed-value floating-rate debt is a technically small innovation relative to today's short-term bills and floating-rate debt, but one with important advantages for financial liquidity, stability and economic efficiency.

This debt becomes electronic, interest-paying money. A transfer of fixed-value debt from one owner to another is the same as a wire transfer of Fed reserves, and that's what "money" is today. It is a riskless store of value, an asset with immediate liquidity.

Interest-paying electronic money has been the ideal of monetary economics for decades. When money does not pay interest, people needlessly economize on its use. Interest-paying money allows the economy to be satiated in liquidity, without danger of inflation or need of deflation.

Over the last few decades, our economy developed interest-paying electronic money, in the form of interest-paying bank accounts, overnight repurchase agreements, auction-rate securities, prime money-market funds, short-term commercial paper, and so forth. However, this inside money proved susceptible to a run in the Fall of 2008. Fixed-value floating-rate debt is defaultfree and therefore run-free in a way that the U.S. government is uniquely able to provide.

\section{Nominal perpetuities; fixed-coupon debt}

This debt pays a coupon of $\$ 1$ per bond, forever. The Treasury auctions this debt as it auctions long-term Treasuries today, and the Treasury pays down or retires this debt by repurchasing it in a similar auction.

Currently, long-term debt pays a sequence of semi-annual coupons and then a big principal. For example, a 4\% 30-year bond pays $\$ 2$ every six months and then $\$ 100$ in 30 years.

\section{Perpetual debt}

Both of these securities are perpetual. They have no fixed maturity date. As a result, each form of debt is a single security. Newly issued debt is exactly the same security as the debt already outstanding.

By contrast, with the current structure, last year's 30-year bond is this year's 29 year bond. It is a different security from this year's 30-year bond. As a result of principal payments, the debt is currently fragmented into 375 distinct securities are outstanding (Table 1, below), each with a total size of less than $\$ 50$ billion dollars. If these hundreds of issues are replaced by two uniform securities, each with trillions of dollars outstanding, the debt would become a good deal more 
liquid: bid-ask spreads and other trading costs would decline, and price impact (how much prices go down if you try to buy or sell a large amount) would decline.

Fixed-value debt will become especially liquid. Current short-term Treasury notes, bills and floaters suffer small price fluctuations, triggering tax and accounting costs, as well as bid/ask spreads. With $\$ 1.00$ fixed value, these securities have no capital gains or losses at all, and they can have no big-ask spread.

Conventional debt also needs constantly to be rolled over; the Treasury sells new debt to pay off maturing principal. Potter (2015) reports that in 2014, the U.S. Treasury issued $\$ 7$ trillion of new securities, about half of the publicly held debt, but only $\$ 630$ billion was new borrowing.

One may worry that a roll-over might fail, or that investors might demand very high rates to roll over debt as they did in the Greek crisis. Even if that worry is far-fetched, investors face the cost and nuisance of rolling over their investments, and investors together with the Treasury lose the dealer banks' bid/ask spread every time the debt is rolled over. $\$ 6,370$ billion times even a small spread is a lot of money.

Perpetual debt never needs to be rolled over. Investors may revolt, and cause a spike in interest rates. But they must take the initiative to do so. More importantly, investors never need to do anything to keep their positions going.

Though both kinds of debt are perpetual, one should think of fixed-value floating-rate debt as short-term debt, and fixed-coupon, floating-value debt as long-term debt. Duration - the sensitivity of the value of debt to interest rate changes - is a better measure of short-term or longterm nature than is maturity. Fixed-value debt is completely insensitive to interest rates, just like overnight debt. It is essentially overnight debt that is rolled over by default unless the investor does something about it. Fixed-coupon debt trades the certainty of coupons for short-term price fluctuations, just like today's long-term debt.

Treasury debt is only offered in large denominations, deliberately limiting its liquidity and use by retail investors. Currently Treasury bills, notes, and bonds can only be purchased in increments of $\$ 100$. The standard economic justification is that this practice forces a separation between "money" and "bonds." That distinction is no longer relevant. The whole point of this proposal is to increase liquidity and financial usefulness of debt, to reduce the distinctions between "money" and "bonds." As a consequence, all Treasury debt should be sold in any increment, down to the penny.

\section{Indexed perpetuities}

This debt pays a coupon of $\$ 1$ times the current consumer price index (CPI). For example, the March 2015 CPI is 236.119, meaning, roughly, that a basket of goods costing \$100 in 1982-1984 
costs \$236.119 in March 2015. Then, indexed-debt coupons for March 2015 would pay \$2.36119 rather than the $\$ 1.00$ coupons of nominal perpetuities, on an annualized basis. As the CPI rises and falls, these coupons rise and fall.

Current Treasury Inflation-Protected Securities (TIPS) have a complex inflation adjustment to coupon and principal. Like coupon bonds, each TIPS issue is a different security, and thus small and illiquid. The illiquidity of TIPS was particularly apparent in wide price fluctuations during the financial crisis of 2008. My modified structure would again yield a single, simple, much more liquid, security, with quantity outstanding above a Trillion dollars.

The indexed perpetuity is the cornerstone risk-free investment of modern long-horizon portfolio theory. Economists thought TIPS would be more popular than they are. The complex structure of current TIPS may be holding them back. If so, a simplified security more closely aligned to its economic function should be popular.

Together, these features should result in a more popular security, and improve the functioning of the financial system.

\section{Tax-free debt}

Treasury debt should be free of all income, estate, capital gains, and other taxes.

Optimal taxation principles say not to tax rates of return. These principles are honored a bit in the U.S. with a complicated system of tax shelters and preferences. Tax-free Treasury debt would be a lot simpler and save a lot of lawyer and accountant fees. It would be a very popular security, again allowing the Treasury to sell more at lower rates.

Taxing the interest on debt makes it seem that the Treasury pays less interest net of taxes. But investors who must pay taxes on interest offer less to purchase taxable debt in the first place. Therefore, in the first instance the Treasury gains nothing from interest taxation. In fact, the Treasury can lower interest costs by offering tax-free debt, since taxable investors will voluntarily pay up front the value tax-avoidance costs.

One may suspect that tax-free debt would be a present to high-tax investors. I demonstrate the opposite conclusion. High-tax investors don't have to buy Treasury debt in the first place, and largely don't do so. Under plausible assumptions, then, offering tax-free debt would attract high tax investors back to the Treasury market. It would remove a subsidy to non-taxable investors, such as pension funds, endowments, and foreign central banks, who enjoy high taxable interest rates without paying taxes.

\section{Variable-coupon debt}


Long-term debt should allow the government to temporarily lower coupons without triggering legal default.

This provision would help the U.S. government in times of extreme fiscal stress. Businesses in trouble cut dividends, and then restore dividends when trouble has passed. I propose a structure similar to noncumulative preferred stock. The debt promises a coupon, $\$ 1$ per share or $\$ 1$ x CPI per share. That coupon can be cut, and is promptly restored to the promised level as soon as possible.

The U.S. can cut coupons already. U.S. debt is not collateralized, and the U.S. cannot be taken to bankruptcy court. But cutting coupons or principal of current debt would trigger a legal default, which would be a mess. Bondholders could try to seize government assets, refuse tax payments, and sue. If nothing else, legal default would hobble the debt's eligibility as collateral, and many institutions would be forced to dump the debt by legal and accounting rules.

I contrast this proposal to various proposals for variable-coupon debt, including GDP-linked debt. I argue that this system provides more flexibility. GDP-linked debt can't adjust to a war, when GDP might increase, or to a financial or sovereign debt crisis, in which GDP might not measure well the government's financing need.

\section{Swaps}

The Treasury should manage the maturity structure of the debt, and the interest-rate and inflation exposure of the federal budget, by transacting in simple swaps among these securities.

Suppose that the Treasury wishes to increase the maturity of the debt. Rather than buy back trillions of short-term debt and issue new long-term debt, the Treasury could just enter a large swap of fixed for floating interest payments. Even small banks manage risk in this way.

Swaps would also allow the Treasury to separate the liquidity-provision, financial-stability, and other economic policy goals of its debt management from its risk-management goals. For example, the Treasury could issue lots of money-like fixed-value floaters to satisfy liquidity demand, but swap out the interest rate risk. The special liquidity demand for fixed-value debt attaches to the bond itself, not to its interest-rate risk exposure.

The Treasury can offer a very simple swap contract. The security replicates borrowing a dollar at the floating rate to invest a dollar in fixed-coupon perpetuities. This simple contract is equivalent to a fixed-for-floating swap collateralized by floating-rate debt, with none of the contractual complexities of regular swaps. This swap contract should also be attractive to small businesses and homeowners desiring to manage interest-rate risks, and currently too small to access swap markets, or as the basis for intermediaries to offer similar products. 


\subsection{Limits}

Why stop here? Markets demand all sorts of additional fixed-income products. It is better however for financial intermediaries to create the wide variety of products designed to meet specific and changing retail demands, backed or hedged in part by Treasury debt. That is the private sector's comparative advantage. The Treasury's unique ability is to provide nearly default-free and uniquely liquid debt.

In this chapter, I address economic questions. There are legal questions: How many of these changes could or should the Treasury undertake of its own accord, and how many need enabling legislation? There will also be political questions: Some parties may benefit from current Treasury debt structures and will object to changes. I do not limit analysis of economic possibilities by an amateurish analysis of current legal, accounting, or political limitations. In part, if we can agree on the desirability of a new debt structure, then the legal, accounting, and political landscape will change.

This chapter is informed by a long economic literature on optimal taxation, optimal maturity structure and optimal state-contingency of government debt, monetary-fiscal policy coordination, sovereign default, and so forth. I do not tie the analysis to a particular model in this tradition, or to a particular model's recommendation for optimal debt management and monetary policy. My goal is to assemble the tools recommended by this literature, leaving just how and when to use those tools in the background. We can agree on the tools while disagreeing how best to use them. For example, we can agree that swaps are a desirable way to adjust the interest-rate-exposure of the debt without agreeing on whether now is a good time to go long or to go short.

Any paper on government debt should start with a nod to the Modigliani-Miller theorem. If markets are frictionless, if taxes are lump sum, and if representative agent conditions hold, then the structure of government debt is irrelevant. (Chapter I also discusses this point.) Any gains or losses the government makes on its bond portfolio are paid by the same taxpayers who hold the bonds.

My analysis is rooted in three particular failures of this theorem: Government bonds and money have important liquidity and collateral value in the financial system, taxes distort, and default and inflation are costly.

Now, let's look at each security in detail. 


\section{Fixed-value floating-rate debt}

In place of short-term bills and notes, the U. S. Treasury should issue perpetual, fixed-value, floating-rate, electronically-transferable debt in arbitrary denominations. I need a sexy name. "Treasury electronic money" describes its function. "Fixed-value floaters" describes it as a debt instrument.

The value of this debt is always $\$ 1.00$ per bond. That value is guaranteed by a Treasury commitment always to buy or sell such debt at a price of $\$ 1.00$. If a bank delivers $\$ 1.00$ of reserves to the Treasury, the Treasury issues one bond, and vice versa. If an individual or nonbank institution wants to buy or sell a bond, they direct their bank to deliver or receive reserves to the Treasury. To the investor, this Treasury debt then looks like a money market fund, or interest-paying reserves at the Fed. Reserves are freely convertible to cash, so the relative price of Treasury electronic money and cash is similarly fixed.

In addition, anyone also has the right to pay taxes or receive government payments directly to or from fixed-value debt. Tax payments made earlier than due receive interest at the Treasury floating rate.

At one level, there is little difference between the Treasury's commitment to accept maturing debt at face value for tax payments, vs. its commitment to exchange debt with reserves, with the Fed's commitment to exchange reserves for currency, and the Treasury's commitment to accept currency and reserves for tax payments.

But the direct commitment is clearer, simpler and stronger. It allows Treasury debt to operate as full-fledged electronic money independently of banks and the Federal Reserve. Fundamentally, interest-paying money gains its value by the government's commitment to accept that money at face value for tax payments, not by its scarcity. (For example, see Cochrane 2005, 2014b.) I'll take your Treasury debt in exchange for an economics lecture, if I know that I can use that debt to pay taxes, or sell it to someone else who has that need. The Fed might change who can hold reserves, or other terms of their use. Banks and bank reserves might fade away in an electronic payments economy. When considering the legal definition of a security that will last forever, a backstop direct grounding of that security's definition and value, independent of current monetary arrangements, is desirable.

The floating rate is paid daily, by incrementing the number of bonds in the investor's account. The full equivalence of fixed-value debt with reserves means there is no reason to daily send reserves to a separate bondholder's bank account. 


\subsection{Setting the floating rate}

The Treasury has the legal right to set the floating rate as it wishes. The legal right in this security is the right to a $\$ 1$ value, to exchange the security for $\$ 1$ of reserves and hence currency at any time and to extinguish $\$ 1$ of tax liability by its surrender. This right to leave at any moment, not an interest-rate formula guarantees the investor's subsequent rate of return.

Within the legal right to set the floating rate, however, the Treasury will need a policy. That policy may change over time as the financial environment changes.

In the current environment, it is natural for the Treasury to benchmark the floating rate to the interest that banks receive on reserves at the Federal Reserve. Banks are then indifferent to the two assets. The Treasury can manage the amount of floating-rate debt outstanding by offering a few basis points more or less than interest on reserves to attract or to discourage investors.

A policy of benchmarking to interest on reserves also makes clear the intent of this security: to offer the same security as banks have at the Fed - electronically transferable interest-paying money - to the general public. And it clearly preserves the understanding that the Fed is in charge of short-term interest rate policy. The interest-rate ship sails more smoothly with one captain.

That policy, however, presumes that the Fed maintains its currently-envisioned operating procedures, consisting of abundant excess reserves, paying interest on reserves within basis points of market rates, and using interest on reserves as the policy instrument. If the Fed goes back to a small amount of non-interest bearing reserves, the Treasury will have to set its own rate.

The Treasury could benchmark the rate to an index of market rates, including the federal funds rate, repo rates, or Libor as well as the Fed's interest rate on reserves. The Treasury could also set the rate directly as a policy tool, as the Fed sets interest on reserves.

The Treasury could also conduct daily auctions to reset the rate. The price is fixed at $\$ 1$, but the Treasury can take bids for how much investors want to buy and sell at each possible interest rate. Market orders specify a quantity at any rate. The interest rate paid to all investors is the one that clears the daily market. The Treasury can sell or repurchase debt via a market order, via a sloping set of orders, or it can run a corridor system, with small market orders and large bid and ask orders separated by a spread. That system would allow the rate to respond to market forces inside a band. Many central banks operate such a system.

The main difference between all these alternatives is how much the Treasury wishes to control day to day variation in the floating rate vs. variation in the relative quantity of Fed 
reserves and Treasury debt. The total quantity of reserves plus debt held by the public remains fixed. It is, again, a largely technical issue not essential to the security.

\subsection{Why?}

Economists have long dreamed of interest-paying money. It fulfills Milton Friedman's (1969) optimal quantity of money without inflation or deflation. Money, either paper or electronic, is essentially free to produce, so the economy should be satiated in the liquidity that money provides. Financial arrangements designed to save on the lost interest of holding money are a social waste. The economy gains the area under the money demand curve. For Lucas (2003) estimated as at least 1\% of GDP. Electronic money is particularly attractive in allowing very low cost secure transactions.

More importantly, interest-paying Treasury money benefits financial stability. Our economy invented interest-paying electronic money in the form of money market funds, overnight repurchase agreements, and short-term commercial paper, and found it useful. But that inside money failed, suffering a run in the 2008 financial crisis. Treasury-provided interest-paying electronic money is immune from conventional runs. (For more, see Cochrane 2014b.)

Providing money is a key government responsibility. In the 19th century, the Treasury provided coins. Printing advances allowed for paper money, and banks issued notes. Notes were convenient, being a lot lighter than coins. But there were repeated runs and crises involving bank notes. Late in the $19^{\text {th }}$ century, the U.S. government issued paper money, which might inflate, but cannot suffer conventional default or a run. That money eventually drove out private banknotes, and that source of financial crises ended. (Crises involving demand deposits did not end, but here the U.S. tried a different policy response, deposit insurance and risk regulation, which has not worked as well.)

In the 21st century, following the revolutions in communications, calculation, and financial engineering that make interest-paying money possible, the Treasury has the same natural monopoly in providing default-free and run-free interest-paying money.

Treasury debt is already liquid and "money-like," and the Treasury already realizes this function in its issuance strategy ${ }^{2}$ Fixed-value electronically-transferable floating-rate debt will be even more liquid and desirable than short-term bills and current floaters are. Its bid-ask spread will be set entirely by technological limitations - how much the Treasury charges for changing bits in its computers, which could be zero. You can't have asymmetric information or price pressure of a fixed-value security. The market depth will be several trillions, rather than the tens

${ }^{2}$ See http://www.wsj.com/articles/treasury-plans-more-short-term-debt-1430966689 
of billions of typical Treasury bills. It can be more liquid even than bank reserves, since anyone can hold Treasury debt but only banks can hold reserves. Recent short-term Treasury interest rates persistently below interest on reserves is evidence that such liquidity inversion is possible.

The Treasury should facilitate electronic transactions in this fixed-value debt. Its existing services such as Treasury Direct, Direct Express and Pay.gov are an important foundation. Exchange and settling via Treasury accounts can be handled among financial institutions just as Fedwire handles the exchange of reserves and current Treasury debt.

However, the Treasury does not necessarily have a comparative advantage in the design and operation of large-volume low-cost secure transactions services, especially ones open to retail customers. An industry of money market funds and electronic exchanges should be allowed and encouraged to offer transactions services accounts in or backed by fixed-value treasuries. I should be able to buy a cup of coffee by bumping a cell phone and transferring $\$ 2.53$ of an account consisting of or backed $100 \%$ by fixed-value treasuries. And paying something like bitcoin's minuscule transactions fees rather than the $4 \%$ fee charged by credit card companies to do so.

The carrot: If fully invested in fixed-value Treasuries, and walled off from bankruptcy of related or sponsoring financial institutions, such intermediaries need no risk regulation. They are as un- "systemic" as a financial institution can be. The only cause for regulation is to ensure against fraud.

The Treasury already offers floating-rate debt in addition to short-term Treasury bills. Current floaters have a two-year maturity. They pay the same rate as 13 -week bills. Though frequent resetting typically results in small variation in market value, their market values do vary. And the nature of the index matters to investors in the absence of the fixed-value guarantee.

In one sense, then, fixed-value floaters are just a small improvement on what we already have. This fact should allay fears that the final step will open a Pandora's box of unintended consequences. On the other hand, the small changes - removing the fixed maturity, fully fixing the price at $\$ 1.00$ - will quite substantially increase the liquidity and value of the securities as true "electronic money."

\subsection{Why not the Fed?}

The same economic benefits could be achieved if the Federal Reserve were to open interestpaying reserve accounts to the general public. The Fed would likely have to increase substantially the size of its balance sheet, buying up most of the Treasury's short-term debt to issue such reserves. 
However, the Fed is a central bank, and by tradition and law only transacts with banks or other large financial institutions. Offering accounts directly to the public requires a big institutional and legal change.

By contrast, the Treasury already sells to the public. If people can buy bonds from the Treasury webpage, why not a "bond" that happens to work just like a money market account? The Treasury has provided currency. Why not currency that pays interest?

In sum, a technically small modification of existing Treasury securities, easily within the Treasury's legal authority and traditional scope of operation, is an easier institutional path than modifying the Fed's legal authority and scope of operations.

\subsection{Monetary policy and price-level determination}

How is the price level determined? The traditional story is that people hold bonds for saving, and non-interest-paying money for quick liquidity and to make transactions. The Fed controls the price level by controlling the quantity of money relative to bonds, i.e. the split of government liabilities between interest-paying and non-interest-paying flavors.

Fixed-value, floating-rate, electronically transferable Treasury debt, held in large quantities so that we are satiated in liquidity, eliminates what is left of the rapidly-vanishing distinction between "money" and "bonds." An account held for savings purposes happens to function as excellent money. Must we hobble Treasury debt for price level control?

No. We crossed that Rubicon long ago. The Federal Reserve's large balance sheet and interest-paying excess reserves undid the classic tale of price-level control. Private interestpaying electronic money in the form of interest-paying checking accounts, money market funds, overnight repo, commercial paper, auction-rate securities, and so forth undid that tale. The fact that banks long ago started getting most of their funds from liabilities that do not require reserves, and the fact that the Fed stopped pretending to target monetary aggregates, fixing interest rates instead and letting the quantity of money be whatever is desired at that rate, undid that tale.

Monetary theory is now based entirely on interest rate targets, not the rationing of noninterest-bearing cash or inside money. Thirty years' experience of stable inflation with no control at all of monetary aggregates and despite the spread of interest-paying money confirms the modern theory. If banks can have interest-paying reserves and wholesale funding, if financial institutions can have a large shadow-banking system, and if the Treasury can offer short-term debt so liquid it pays a lower rate than bank reserves, all without undermining price-level control, the minor extension of floaters and bills to fixed-value debt will not have a dramatic effect. (Woodford 2004 is the standard summary of price-level control with interest rate targets in 
modern macroeconomic models. Cochrane 2014c offers an even simpler view based on the fiscal foundations of money, which does not require a Taylor rule.)

\subsection{Credit}

A common objection is that banks need to offer fixed-value deposits in order to supply credit to the economy. If the Treasury offers attractive fixed-value deposits instead, banks will be deprived of a key source of funds and will not be able to offer enough credit.

The simple form of this argument falls apart on basic accounting. I advocate replacing existing short-term Treasury debt, composed of bills and short-dated notes, with fixed-value floating-rate debt. The total amount of government debt in private hands need not change, so the total amount invested in the banking system and private credit markets need not change. An expansion of government debt overall can crowd out private lending, yes, but the form of government debt is of little consequence.

\section{Fixed-coupon perpetuities}

The U.S. should introduce perpetual long-term debt. This debt pays a \$1 coupon per bond, forever. As interest rates rise and fall, the price of perpetual debt will fall and rise. The Treasury will auction the debt at whatever price the market will pay. If (hopefully, when) an era of primary surpluses returns, the U.S. will repurchase outstanding debt at auction.

Coupons of perpetual debt can be paid in shares of floating-rate debt, since the latter always carry the right to obtain reserves and therefore currency, and they can be used for tax payments. The coupons could be paid daily, much simplifying the accounting of Treasury debt purchases.

\subsection{Why?}

As explained above, perpetual debt folds all existing issues into one security, thus greatly deepening the market, liquidity and collateral value of debt. Perpetual debt is the only way to produce a single security whose characteristic does not change with the passage of time. We should be rewarded with lower interest rates for the taxpayer as well as a better-functioning monetary and financial system.

For example, if the Treasury sells a 30-year bond this year, that bond becomes a 29-year bond next year, when the Treasury sells a new 30-year bond. The 29- and 30-year bonds are different securities. If their prices diverge, arbitrageurs cannot readily correct that difference. You cannot short-sell a 30 year bond and deliver a 29-year bond in its place. If you hold the 29-year bond as collateral, you must deliver back a 29-year bond, not a 30-year bond. If you want to buy a 
long-term bond, you have to choose either the 29 or the 30 -year, and only half of the bondholders can bid on your offer.

And there are hundreds of different Treasury securities outstanding. Table 1 shows that the nearly $\$ 13$ Trillion of debt is carved up in to 375 distinct securities, with typical issue sizes well below $\$ 50$ billion each.

By contrast, if long-term debt were structured as a perpetuity, long-term debt would consist of a single issue, with trillions of dollars outstanding. New debt would be an expanded issue of the same security, literally the same CUSIP, completely fungible with outstanding debt. An investor buying or selling debt, would face a market thousands of billions deep, not a few tens of billions. The spread in yields between on-the-run (newly issued) and off-the-run (older) issues would disappear, as all securities would be on-the-run. Arbitrage spreads between bonds with different coupon levels (Pancost 2015) would disappear. Bid-ask spreads would likely tighten, and the price impact of trading large blocks likely evaporate.

Table 1. Structure of U.S. Treasury Debt, March 2015.

\begin{tabular}{llll} 
Security & Number & Total Value & Average Issue Size \\
\hline Bills & 32 & $\$ 1,478$ & $\$ 46$ \\
Notes & 232 & $\$ 8,264$ & $\$ 36$ \\
Bonds & 67 & $\$ 1,607$ & $\$ 24$ \\
TIPS & 39 & $\$ 1,075$ & $\$ 28$ \\
Floating & 5 & $\$ 205$ & $\$ 41$ \\
\hline Total & 375 & $\$ 12,621$ &
\end{tabular}

Note: Dollar quantities are in billions. Source: Statement of the Public Debt, http://www.treasurydirect.gov/govt/reports/pd/mspd/2015/2015_mar.htm.

Already, U.S. debt is valued for its liquidity and collateral value. (For example, see Duffie (1996), Krishnamurthy and Vissing-Jorgensen (2012) Gorton and Ordoñez (2013).) Yet liquidity and collateral value are not as great as they could be, evidenced not only by the existence of spreads, but also by occasional trading glitches (See Potter (2015)) and reports of "collateral shortage" of liquid on-the-run Treasuries.

\subsection{Price impact}

One may worry that the when the Treasury repurchases debt, it will drive bond prices up, thereby paying more than it would have by paying the principal values of maturing debt. On reflection, this is unlikely to be a substantial problem. 
Purchases affect prices, or occasion bid-ask spreads, when the buyer conveys information by the offer, or when buyers show up unexpectedly. Treasury purchases to repay debt as a consequence of budget surpluses will convey no information about interest rate movements. And the Treasury's purchases will be slow, predictable, and widely pre-announced.

The Treasury already sells debt with little price impact by auction. Since 2000, the Treasury has successfully repurchased outstanding issues, even illiquid and off-the-run issues, with little price impact. And one should compare any remaining price impact to the fees currently paid to roll maturing debt.

\subsection{Call option}

One might want to complicate the debt by adding a call option. For example, the Treasury can always repurchase $\$ 1$ perpetuities for $\$ 100$. I do not think such a provision is desirable. The Treasury has abandoned the once-widespread inclusion of call options in existing long-term debt. The wisdom of that decision extends to perpetuities.

A call option complicates bond pricing. There is no simple formula for the value of a callable perpetuity.

A call option either requires a stated policy for when the call will be exercised, or it adds speculation about when the government will exercise its option, and pressure to call or not, with billions of dollars on the line. Calling the entire stock of debt, and reissuing debt with a different call option would also be a momentous and expensive operation.

To what end? If it is to avoid the price impact of repurchasing debt on the market, adding a call option in today's liquid markets seems like a minor savings and a major headache. If it is to manage interest rate risk, it comes at the wrong time. Times when interest rates are low and bond prices are high are good times for government finance. If risk management is the goal, the Treasury should buy put options, the right to sell debt when rates are high.

In any case it would be better for the Treasury to buy call options directly. There is no reason in a modern financial market for the Treasury to bundle the bond with the call option.

\subsection{Coupon bonds and history}

An obvious objection: since so much corporate and government debt consists of coupon bonds with principal payments at a finite maturity, surely there is a strong economic reason for this structure? I am not able to find one.

Government perpetuities are not a new idea. Some of the first government debt consisted of annuities and perpetuities. The towns of Douai and Calais sold annuities and perpetuities in 1260 (Kohn 1999 p. 5). Venice’s 1262 Monte issued perpetual debt paying 5\% interest semi-annually. 
Venice's debt, and that of following Monti such as Florence's, were also fully transferable, and publicly traded, in markets facilitated by brokers. Bonds were recorded in book-entry form, and could be "encumbered with a lien as security for loans, for real estate transactions (to protect against defects of title), and for dowries. Indeed, shares were preferred to other forms of security because no litigation was necessary in case of default." (Kohn 1999 p.10.) The value of government debt as collateral goes back a long way too!

More recently, perpetuities were the nearly exclusive source of financing for 19th century Britain, including a $250 \%$ debt to GDP ratio at the end of the Napoleonic wars (Homer and Sylla 1996, p. 189 ff.) Some early American debt was also issued without fixed maturity, starting with Alexander Hamilton's refunding of the 1790s (p. 293).

Many early perpetuities had what we now call a call option, for example being described as “3\% perpetuities" when the government had the right to repurchase each $£ 3$ of coupons for $£ 100$. However, in my reading these options had a different purpose than the modern concept of an interest-rate derivative. They allowed the government to pay back the debt when the government had the resources to do so, putting off repayment in case of war or other time of fiscal stress, and they helped to overcome what might have been significant price impact of repurchases in an era of horse and sail communication. Yes, the option was used on occasion to lower coupons, as in “Goschen's conversion” of 1860 (Harley 1976) - which caused a lot of volatility, in line with my criticism - and the 2014 repurchase of $4 \%$ perpetual bonds issued in the $1920 \mathrm{~s}^{3}$. But the fact that governments occasionally use the interest-rate option ex-post as an interest rate derivative does not imply that this option was centrally important for issuing the debt ex-ante.

Corporate bonds almost always have finite maturity and principal payments. Corporate perpetuities exist though they are rare. (ING sells perpetual exchange-traded debt with ticker INZ.)

There are several legal and accounting reasons why corporations might want to issue, and their investors demand, finite-maturity coupon plus principal debt.

In default, corporate bondholders are paid in proportion to the undiscounted principal amount of the bonds. This fact gives a strong reason why investors demand a security with a stated principal value, and sufficient coupons to bring the market value near par. The IRS may refuse to count perpetuities as "debt" for the deductibility of corporate taxes, and accounting or banking regulation may not count such perpetuities as a safe "debt" asset. Bankruptcy courts may put perpetual debt below other long-term unsecured debt. But none of these bankruptcy or tax issues apply to U.S. federal debt.

\footnotetext{
${ }^{3}$ Stubbington, Tommy, and Ben Edwards. 2014. "U.K. to Repay First World War Bonds" Wall Street Journal, Oct 31, http://www.wsj.com/articles/u-k-to-repay-first-world-war-bonds-1414745764
} 
Default is not entirely unimportant. The U.S. has defaulted, for example in the abrogation of gold clauses. The recent debt limit controversy raised the possibility of a technical if not economically important default, in the form of delayed coupon payments. A legal statement of rights in default will be an important part of perpetuity design. An otherwise meaningless par value, say $\$ 20$ for each $\$ 1$ of coupon is one possibility.

Corporate debt-holders might wish their debt to correspond to tangible assets or investment projects, and corporations typically do not have infinitely-lived tangible assets against which to borrow. But U.S. federal debt is backed by the stream of net surpluses that the U.S. government can extract from taxpayers, which is a much longer-lived asset.

U. S. mortgages and mortgage-backed securities consist of a stream of coupons but no principal. This fact verifies that principal payments are not crucial for debt to be sold. The existence of the underlying asset (house) which can be seized on default adds to the suggestion that corporate principal is there to establish a claim in default.

In summary, I do not see in theory or experience an indication that there is something deeply wrong with perpetual government debt, especially for a solvent modern government of an advanced country, borrowing its own currency.

\subsection{Wholesale, retail, and hedging}

Fixed-income markets demand a great variety of additional securities. People and institutions want to match specific liability streams, to hedge specific fixed-income risks, or to take other risks in pursuit of greater returns.

As a general vision, it seems best for the government to provide a few, simple, deep, liquid, and default-remote benchmark securities, the provision of which is the government's unique comparative advantage. It is better for financial intermediaries to create products that fill the many, varied and shifting specialized needs of retail individual, financial, and corporate clients, including coupon and zero-coupon bonds, mortgages and loans, customized swaps, caps, floors and other derivatives, annuities, life insurance, pension products, and estate planning products. And any fragmentation of Treasury debt lowers its depth and liquidity.

Treasury securities serve central price-discovery, hedging, and benchmarking functions. Several commenters have suggested that the Treasury should continue to offer a spectrum of coupon bonds, notes, and bills, so that intermediaries can better price and hedge corporate bonds. On examination, however, I think this is a weak argument. 
First, the STRIPs program can and should continue, by which coupon bonds are unbundled into zero-coupon elements. ${ }^{4}$ Intermediaries will then have access to a deep and liquid market for zero-coupon debt, from which they can synthesize and price coupon bonds if they so desire. STRIPS based on perpetuities should be more abundant and more liquid than those based on current coupon bonds, since the distinction between principal and coupon STRIPS will vanish and there is only one security to reconstitute.

We do not need to create an infinite number of zeros. A perpetuity can be stripped, for example, into 30 annual zero-coupon bonds and a 30-year futures contract.

I suggested that coupons be paid daily, to avoid accrued-interest accounting in bond sales and pricing. Zero-coupon strips issued at annual or quarterly intervals can then include accrued coupons, brought forward at the floating rate. The zero-coupon bond for Dec 31 2025, for example, will the cumulated value of $\$ 1$ invested in floating-rate debt from January 1 to December 31 of that year.

Second, with the advent of computers and modern fixed-income modeling, financial intermediaries do not need to observe comparable Treasuries in order to price and hedge corporates and other retail offerings. Almost all movements in the Treasury yield curve can be spanned with level, slope, and curvature factors, plus smaller liquidity, credit and other factors. Today, fixed income instruments are priced and hedged with liquid securities that span these factors, not with potentially illiquid Treasury instruments that replicate cashflows.

Third, corporate and municipal bonds are subject to credit risk and are typically callable. Valuing or hedging a corporate bond is not so simple as looking up a Treasury with similar coupon and maturity. Credit and liquidity spreads are fairly high-tech issues these days.

Fourth, valuing and hedging fixed-income securities, including call options, prepayment options, state-contingent default, and so forth, also requires one to measure, model, and hedge interest-rate volatility. Volatility is poorly spanned by any combination of discount bonds.

\subsection{Intermediate-maturity supply?}

The question, then, is not whether an adequate number of liquid hedging instruments will exist. They will. If someone wants to buy a risk-free coupon bond, they will be able to do so. The question is whether markets inexorably demand to hold overall, netting out buyers and sellers, a

\footnotetext{
${ }^{4}$ A zero-coupon bond is a simple promise to pay $\$ 1$ at a fixed point in time. A coupon bond is a bundle of zero coupon bonds. A quick view of the mechanics: "Under the STRIPS program, U.S. government issues with maturities of ten years or more became eligible for transfer over Fedwire. The process involves wiring Treasury notes and bonds to the Federal Reserve Bank of New York and receiving separated components in return. This practice also reduced the legal and insurance costs customarily associated with the process of stripping a security." http://www.ny.frb.org/aboutthefed/fedpoint/fed42.html
} 
character of securities different from what the Treasury can supply by a combination of fixedvalue and fixed-coupon perpetuities and swaps between these two. Will an important scarcity premium emerge in the intermediate-maturity strip market?

To ponder this question, we must think about what characteristics of debt truly matter. Modern financial analysis recognizes the very strong common movement among Treasury securities. We do not think of separate demands for (say) 9 and 10 year bonds, since they are such close substitutes. Instead, we start by recognizing that almost all movements in the yield curve (the plot of yield vs. duration) correspond to level, slope, or curvature patterns. Then, the risk of any portfolio of Treasury securities is very well described by its duration and convexity first and second derivatives of a bond's value with respect to its yield.

Now, by varying the supply of fixed-value and fixed-coupon debt, plus swaps between their cashflows, the Treasury can provide the market any duration it wants, any exposure to level vs. slope shocks, and any special liquidity demand for fixed-value or fixed-coupon debt. Thus, a scarcity premium must mean that the market demands more or less overall exposure to the curvature factor (intermediate yields rise, long and short yields decline) or more or less convexity, than the Treasury can provide after meeting the market's demand for duration, or level and slope exposure.

Is that the case? Would such a demand, unmet, lead to a yield curve distortion significant enough to affect overall Treasury financing costs or the functioning of the financial system? We don't really know. Bit if it turns out to be the case, that doesn't mean we must keep 375 distinct coupon bonds and roll over half the debt each year. A single or small set of securities focused on providing the net exposure to curvature or convexity would do.

The Treasury could issue additional zero-coupon bonds. For example, the Treasury could issue 10-year zeros and let them mature, rolling over each matured issue to a new issue. The Fed could also issue strips in the middle of the term structure, and buy long and short-dated maturities.

Alternatively, the Treasury could issue a single additional perpetuity with a geometrically declining coupon. ${ }^{5}$ For example, the coupon could be $\$ 1$ in 2020 , and decline $5 \%$ per year, paying $\$ 0.95$ in 2021, $\$ 0.95^{2}=\$ 0.9604$ in 2022 , etc. When the coupons get too small, say $\$ 0.10$, they can be re-based to $\$ 1.00$ for convenience. This security behaves like an intermediate maturity bond. Yet it is always the same security through time, never needing to be rolled over, and allowing the kind of market depth that the level perpetuity offers.

\footnotetext{
${ }^{5}$ I thank John Campbell for this clever idea.
} 
To be specific, the duration D of any bond measures how much a bonds' price $P$ falls when its yield $y$ rises,

$$
D=-\frac{1}{P} \frac{d P}{d y}=\frac{1}{y+g} .
$$

For zero-coupon bonds, the duration equals the maturity. For a perpetuity whose coupons decline at rate $g$ ( $g=0$ for the level perpetuity) the duration is the inverse of $y+g$. So, at a $5 \%$ yield, the duration of the perpetuity is 20 ; it acts like a 20-year zero-coupon bond. A perpetuity with a $5 \%$ declining coupon acts like a 10-year zero-coupon bond. This declining perpetuity also has less convexity than the level perpetuity, and when stripped produces more short-dated zeros than long-dated zeros.

Darrell Duffie's thoughtful comment goes beyond demand for curvature or convexity to think about demand for specific issues. He notes, for example, occasional strong demand for the most recently issued 10-year coupon bond, driving its yield below those of very similar bonds; and episodes of collateral shortage and trading glitches for specific issues. He concludes that the Treasury must continue to issue 2, 5, and 10 year par-value nominal coupon bonds, and carefully manage their supplies.

This is an important comment, eloquently summarizing objections I have heard from several financial market participants. It's especially important because these are precisely the kinds of problems that perpetuities are meant to solve by creating a single, very deep market.

The question is, whether an inexorable time-varying total demand for 2, 5, and 10-year par value coupon bonds is written into the structure of the financial system? Or, has supply created its own demand? If the Treasury were to issue only a perpetuity, would we see collateral and hedging uses migrate to that new security, leaving behind a calm term structure of zeros? Or would my liquidity provision project fail, and we see large fluctuations in the price of synthetic 2 , 5 , and 10 year coupon bonds, because of an unaltered underlying and fluctuating demand for those specific securities?

This is the core disagreement, and it is resolvable by data and experience. The Treasury can issue perpetuities together with the current spectrum of bonds, and the Treasury can wait to stop issuing current bonds until market demand has waned.

\subsection{Accounting: maturity and face value}

One reason that current floaters have a two-year maturity is the question of how to account for their maturity. Perpetuities have infinite maturity, which would cause trouble with the Treasury's average maturity reports. 
Maturity of coupon debt, variable-coupon debt, floating-rate debt, or debt with call or other options is a fairly meaningless concept. Weighted average maturity is a misleading guide to the Treasury's interest-rate exposure, the frequency of rollovers, or much of anything else. Duration, convexity, three-factor sensitivities, and schedules of coupon and principal payments are better measures and easy to compute.

Much of the Treasury's accounting, including the Treasury Bulletin and Monthly Statements of the Public Debt, and the delightful "debt to the penny" website, report face values. Perpetuities have no meaningful face values. The Treasury will have to report the coupon value, market values, or use a benchmark yield.

These accounting and reporting issues should not get in the way of issuing useful securities. It's time to modernize the accounting, not to structure the debt around traditional but misleading numbers.

\section{Tax-free debt}

Treasury debt should be free of all tax, including personal and corporate income tax, capital gains tax, and estate taxes. The state and local exemption for federal interest should be extended to estate taxes and capital gains taxation. Strips created from tax-free debt should enjoy the same tax-free status.

\subsection{Why?}

Optimal taxation principles say not to tax rates of return, which discourage savings. ${ }^{6}$ Perhaps reflecting these ideas, the U. S. government maintains a complex system of tax-sheltered investment vehicles. Tax-free federal debt would be a far simpler security to provide for some of the same purposes.

Borrowing and then taxing the interest is a curious practice. If the government taxes interest, people are willing to pay less for the debt up front. The government does not, in the end, borrow money on any better terms. An explicit analysis of this point follows.

Taxing capital gains of Treasury debt is a particularly curious practice. Bond prices are stationary, unlike stocks. If bond prices fall this year, they must rise eventually. Thus, a capital gain this year must be matched by a capital loss in the future. Taxing realized capital gains makes treasuries less liquid for taxable investors, and thus for the market. We see complex tax avoidance strategies involving municipal debt, even though its interest is not taxable.

${ }^{6}$ Chalmley (1986), Judd (1985). See Atkeson, Chari, and Kehoe (1999) and Mankiw, Weinzierl, and Yagan (2009) for excellent reviews. 
A substantial proportion of the taxation of Treasury debt is taxation of nominal interest that reflects to inflation. Taxing inflationary gains is a bad idea.

The current market for Treasury debt is segmented, with few taxable investors holding any debt. Eliminating the taxation of federal debt will draw taxable investors back to the market, broadening demand for the debt.

In sum, by marketing what should be a very popular and liquid security, the government could sell more debt at lower net interest costs, and improve economic efficiency.

The main motivation for taxing government debt is the idea that by doing so the Treasury avoids an implicit subsidy to high-tax-rate investors, and thus pays less net interest overall. I demonstrate that this objection is very likely untrue. Offering the debt in tax-free form is likely to reduce the government's interest costs, save the economy substantial costs of tax evasion and sheltering, and reduce an implicit subsidy to non-profit, well-sheltered, and foreign (non-taxed) investors. The basic reason is simple: high-tax-rate investors escape taxation by refusing to buy taxable Treasury debt in the first place. Maintaining high tax rates on income from Treasury securities only provides the illusion of progressive taxation.

It would be better for tax-free debt to be so defined, legally, and interest and capital gains not even declarable, rather than to offer tax exemptions for income from federal debt. The latter approach will be tempting, as it will allow Congress to maintain the appearance of progressive taxation, and to limit the tax deductibility in various ways, likely excluding high-income households, or other unpopular taxpayers such as hedge funds or their managers with carried interest income, as it limits participation in other investment shelters. The myRA program is essentially this complex structure.

But that approach would not make anything simpler. It would be much less likely to attract the high-tax and well-sheltered clientele back to Treasury debt. Most of all, deductibility provisions in the tax code can always be revisited. That may be good for an annual renegotiation between legislators, lobbyists, and beneficiaries. But it is not good for initial investment, and raising the initial price of Treasury debt - the whole point of any savings.

\subsection{Taxation of Treasury debt}

Treasury debt is subject to complex taxation of interest, capital gains, and in estates. Bonds issued at discount generate annual tax liabilities. Bonds purchased at premium generate a loss, which must be amortized against ordinary income. The inflation adjustments in TIPS generate taxable income.

There are some precedents for tax-free and tax-advantaged Treasury debt. Treasury debt is exempt from state and local income taxes. Federal taxes on savings bonds can be deferred until 
bonds are redeemed or reach final maturity, and interest can be excluded from tax altogether if the bondholder pays college tuition in the year that bonds mature or are sold. ${ }^{7}$ Historically, some debt could be used at par to pay taxes, even if its current value was below par. In the myRA program, people can start a Roth IRA with Treasury investments. This is functionally tax-exempt Treasury debt, though with a lot of complex rules and income limits attached.

Returns on Treasury debt can also be sheltered. Yet sheltering any investment is a complex process. Put as much as possible into 401(k), 403(b), IRA, Roth IRA, 526, etc. Carefully time capital gains and losses. Mitt Romney's \$100 million IRA based on capital gains of carried interest is a famous example. Plan estates carefully, setting up trusts early, gifting properly, arranging capital gains to occur post-gift, and so forth. Taxation can also be avoided by putting Treasury investments through tax-preferred intermediaries, such as pension funds, especially in the case of government or nonprofit employees, or life insurance.

IRA and similar plans may appear to tax rates of return, since they are taxed as ordinary income on withdrawal. But they do not. If you earn income $Y$, pay income taxes $\tau Y$ leaving aftertax income $(1-\tau) Y$, and then are able to invest with a tax-free return $(1+r)$, you end up with $(1-\tau)(1+r) Y$. If you earn income $Y$, invest the pre-tax earnings in an IRA that allows a tax-free return $(1+r)$, you have $(1+r) Y$ in your retirement account. You pay income taxes on withdrawal, leaving $(1-\tau)(1+r) Y$ - exactly the same amount.

In sum, the Treasury already collects well below the statutory rates of taxation on Treasury interest. Yet at a large cost in money and in simplicity. To a taxable investor, buy it once and forget about all that has a great appeal.

Estate taxes are particular objects of costly avoidance. There's nothing like a once per generation $40 \%$ marginal rate, or the larger generation-skipping rate, to focus one's attention on estate planning and avoidance. As a result the Treasury gets very little revenue from the estate tax and people spend a lot of money avoiding it. If Treasury debt were to pass unhindered through estates, that would truly bring back high-tax investors. If the Treasury can, as I suggest, harvest current tax-avoidance costs, that would be a proportionally large amount.

\subsection{Analysis of tax-free debt}

Here I verify analytically the claims made above: First, the Treasury need not pay higher interest costs by issuing tax-free debt, because investors will pay more for that debt upfront. Second, by offering tax-free debt the Treasury can harvest tax avoidance costs, and thereby lower its net interest costs. Third, when debtholders pay different tax rates, the Treasury is likely to

\footnotetext{
${ }^{7}$ https://www.treasurydirect.gov/indiv/research/articles/res_invest_articles_tax_adv_0604.htm
} 
lower net interest costs, attract high-tax investors back to Treasuries, and eliminate a subsidy to non-taxed investors by offering tax-free debt.

\subsubsection{Tax-free debt need not raise interest costs}

A simple example: Suppose the Treasury offers to pay a $\$ 10$ coupon and $\$ 100$ principal in a year, but taxes the coupon interest $50 \%$. On net, the Treasury only pays $\$ 5$. If investors discount the future at $5 \%$, they will offer $\$ 105 / 1.05=\$ 100$ for the bond, and the Treasury pays net interest of $5 \%$ to borrow money. Now suppose that the Treasury offers the same $\$ 10$ coupon taxfree. You might think that the Treasury now pays $10 \%$ to borrow money, but that would be wrong. Investors would be willing to pay more, $\$ 110 / 1.05=\$ 104.76$, for the tax-free bond. And the Treasury pays the same $5 \%$ net interest to borrow money.

A bit more carefully, in the context of perpetuities, an investor facing tax rate $\tau$ will pay a price

$$
P=\int_{t=0}^{\infty} e^{-r t}(1-\tau) 1 d t=\frac{1-\tau}{r}
$$

for a taxable perpetuity, where $r$ represents the discount rate for after-tax cashflows. To raise $\$ 1$, the Treasury must sell $B=1 / P=r /(1-\tau)$ bonds. Then, net of taxes, the Treasury pays interest $B(1-\tau)=r$ per period. The Treasury pays $r$ in net interest to borrow $\$ 1$, no matter what tax rate is applied to Treasury interest.

This example emphasizes important but frequently overlooked principles of taxation. Taxing income or dividend streams is not the same thing as taxing rates of return. If the government taxes incomes or streams, prices change, potentially leaving rates of return unaffected. For example, corporate profits taxes are unlikely to be borne by shareholders. After a one-time capital loss when the tax is announced, lower stock prices offset higher corporate tax payments leaving an unchanged rate of return.

Equivalently, the burden of taxation depends on the slope of supply and demand curves, i.e. people's ability to change behavior to avoid taxes. In this simple example I assume a flat supply of capital at the after-tax rate of return $r$. Flat supply curves mean that suppliers do not bear any burden of taxation. I examine the flat supply curve assumption below. In a global capital market, replete with tax shelters for investments, it's a good place to start.

Raising taxes on interest would benefit the government after bonds have been sold. But once burned, twice shy investors will not offer the same price the next time around. I consider here only steady state, long-run, taxation in which prices fully reflect following payments, not the classic temptation for a just-this-once capital levy. 


\subsubsection{Tax-avoidance costs}

By offering tax-free debt, the Treasury can collect the costs of tax avoidance, and therefore lower interest costs overall.

Continue the simple example, that the Treasury offers a one-year bond with $\$ 100$ principal, a $\$ 10$ taxable coupon, and 50\% tax rate. Now, suppose that investors can pay $\$ 1$ to lawyers in order to cut the tax rate to $30 \%$. The Treasury gets $\$ 3$, the lawyers get $\$ 1$, and the investor gets $\$ 6$. The investor is willing to pay $\$ 106 / 1.05=\$ 100.95$ for the taxable bond, and gets a $5 \%$ return. The Treasury, however, pays $\$ 7$ of net interest, so the Treasury pays an effective rate of $100 \times(107 /$ $100.95-1)=5.99 \%$. The Treasury has paid the tax-avoidance costs! The Treasury would do better by offering tax-free debt, on which it pays only $5 \%$ as above.

I the context of the perpetuities, let the statutory tax rate be $\tau$, let the proportional costs of tax avoidance be $c$, and let tax revenue received by the government be $\rho$, each per $\$ 1$ of coupons. We have $\rho+c<\tau$ so tax avoidance is worthwhile to the investor. The government pays \$1 in coupons, receives $\rho$ back in taxes, so pays net interest $(1-\rho)$ on each taxable bond. The investor receives coupon $\$ 1$, pays taxes $\rho$ and avoidance costs $c$, so receives net coupon $(1-\rho-c)$. A stream of taxable coupons is then worth $P=(1-\rho-c) / r$ to the investor. Per $\$ 1=P \times$ $B$ borrowed by selling $B$ bonds, then, the Treasury pays net interest

$$
(1-\rho) B=\frac{1-\rho}{P}=\frac{1-\rho}{1-\rho-c} r>r .
$$

By offering tax-free debt, Treasury pays only $r$, as above. By taxing interest, the Treasury ends up bearing the burden of tax avoidance costs and raising its cost of funds.

\subsubsection{Heterogeneous tax rates, tax clienteles and tax efficiency}

Different people pay different tax rates. If taxable and tax-free bonds give the same after-tax return at a tax rate $\tau^{*}$, then it seems that tax-free debt is a present to investors who face higher tax rates. More generally, tax-free debt may be viewed as a loophole, the sort of thing that should be eliminated in a quest to broaden the base and lower overall tax rates.

By the same logic, however, this situation offers a subsidy to low-tax and non-taxed investors, including endowments, central banks, governments, nonprofit corporations, many pension funds, and so forth. They receive an interest rate set by a marginal taxable investor who pays $\tau^{*}$, yet they pay no tax. One could equivalently speculate that by offering non-taxable debt to everyone, they would receive the non-taxable rate like everyone else and the government would save interest costs.

The central issue is, that who holds the debt and what price they offer changes. Whether interest costs rise or fall by offering non-taxable debt depends, among other things, on the supply 
curve, i.e. on the availability of alternative investments. If all investors have access to alternatives with the same after-tax return $r$, then tax-free debt gives the lowest interest cost to the government. When capital can move, the Treasury can give some taxpayers presents but it cannot force taxpayers to suffer low returns.

\subsubsection{Example in which tax-free debt lowers interest costs}

Here is a simple calculation, following Miller's (1977) and Dybvig and Ross's (1986) taxclientele models, in which offering tax-free debt lowers interest costs.

Suppose that people facing tax rate $\tau$ demand up to $X_{\tau}$ dollars of debt, and thus $B_{\tau}=X_{\tau} / P$ bonds, so long as they can earn an after-tax return $r$. They are willing to pay up to $P=(1-\tau) / r$ for each taxable perpetuity.

The government sells $X$ dollars of taxable debt in a uniform-price auction. A price above $1 / r$ attracts no buyers. A price $P=1 / r$ attracts the tax-free investors, giving total demand $X^{d}=X_{0}$. Lower prices then sweep out the demands of investors who face higher and higher tax rates. Supply equals demand $X=\int_{0}^{\tau^{*}} X_{\tau} d \tau$ then determines the cutoff tax rate $\tau^{*}$ and price $P=(1-$ $\left.\tau^{*}\right) / r$.

Investors facing rate $\tau<\tau^{*}$ buy $B_{\tau}=X_{\tau} / P^{*}=X_{\tau} r /\left(1-\tau^{*}\right)$ bonds. The government pays them net coupons

$$
(1-\tau) B_{\tau}=r \frac{1-\tau^{*}}{1-\tau} X_{\tau}
$$

so net coupons per dollar borrowed from these investors are

$$
r \frac{1-\tau^{*}}{1-\tau}>r
$$

Investors facing tax rates $\tau>\tau^{*}$ don't buy any bonds.

Thus, all participating investors get a rate of return greater than or equal to their outside alternative, $r$. In this sense, taxable government debt is a subsidy to low-tax-rate investors.

The Treasury's total interest cost is the weighted average of what each investor gets,

$$
r \int_{0}^{\tau^{*}} \frac{1-\tau}{1-\tau^{*}} \frac{X_{\tau}}{X} d \tau>r
$$

The Treasury pays more than $r$ to finance the debt.

This model is consistent with observations of a downward-sloping demand curve for government debt, but by sweeping out marginal tax rates as debt must be sold to higher and higher tax clienteles, not from liquidity, segmented markets, preferred habitat, or signaling future monetary policy. This model also says that the yield ratio between government and municipal bonds should be related to the tax rate $\tau^{*}$ of the marginal investor for government bonds, not the 
maximum federal marginal rate. Thus the "muni bond puzzle" that this interest spread seems low is not necessarily a puzzle.

Now let the Treasury split its supply $\mathrm{X}$ into taxable $\mathrm{X}^{\mathrm{T}}$ and nontaxable $\mathrm{X}^{\mathrm{NT}}$ issues. The low-tax clientele will buy the taxable issues. But by offering a lower amount of these issues, the Treasury will not have to sweep so deeply into the high tax rates, and it will pay a lower net rate on these issues. High-tax investors buy the tax-free debt. The Treasury pays a return $r$ on the tax-free issues, also less than the net interest costs on all the previous issues. So total net interest costs decline.

To see how this works, let $\tau^{*}$ denote the new, lower, tax rate of the marginal investor who buys taxable debt, determined now by $X^{T}=\int_{0}^{\tau^{*}} X_{\tau} d \tau$. Investors with tax rate $\tau>\tau^{*}$ now buy the non-taxable debt. They offer a price $P=1 / r$ and buy what the government offers at that price. The Treasury's total interest payments are now the sum of taxable and nontaxable payments,

$$
r \int_{0}^{\tau^{*}} \frac{1-\tau}{1-\tau^{*}} \frac{X_{\tau}}{X} d \tau+r \frac{X^{N T}}{X}
$$

Since $\tau^{*}$ has declined, overall the Treasury pays less by offering tax free debt than it did by offering only taxable debt.

This model is admittedly stylized. Still, it captures important real-world considerations: 1) Selling debt at taxable rates to non-taxed or less-taxed investors, implies a subsidized rate of return. Selling non-taxed debt to all investors removes that subsidy. 2) The idea that the government does better by taxing the yields of high-rate investors relies on the belief that such investors will buy government debt despite suffering rates of return lower than they can get elsewhere.

\subsubsection{Example in which taxable debt lowers interest costs}

With a model in hand, one can spot the central assumption: That all investors have access to the same after-tax alternative opportunity $r$. One might say "yes, municipal bonds," but another might swiftly answer that the government should get rid of the municipal bond exemption.

Here is the opposite possibility. Suppose each investor facing tax rate $\tau$ has a best alternative investment that yields an after-tax rate of return $(1-\tau) r$. All his or her investment possibilities are fully taxed, at the same rate. Now each investor is willing to pay the same price

$$
P=\int_{t=0}^{\infty} e^{-(1-\tau) r t}(1-\tau) d t=\frac{1}{r}
$$

for taxable perpetuities. Each investor is willing to pay even more

$$
P=\int_{t=0}^{\infty} e^{-(1-\tau) r t} d t=\frac{1}{(1-\tau)} \frac{1}{r}
$$


for tax-free perpetuities.

If the Treasury issues only taxable perpetuities in this case, who buys them is indeterminate as each investor is indifferent. Let $\hat{X}_{\tau}<X_{\tau}$ denote the dollar value of debt actually bought by investors facing tax rate $\tau$, with $\int_{\tau=0}^{1} \hat{X}_{\tau} d \tau=X=$ supply. The Treasury then pays overall net interest

$$
r \int_{\tau=0}^{1}(1-\tau) \frac{\hat{X}_{\tau}}{X} d \tau .
$$

The Treasury does better if debt happens to be in the hands of highest tax rate investors.

If the Treasury instead issues a mix of taxable and non-taxable debt, then the high-tax investors will buy the non-taxable debt. We will sweep out a similar demand curve for nontaxable debt starting at the highest tax rates. The cutoff tax rate $\tau^{*}$ and corresponding price $P=1 /\left[\left(1-\tau^{*}\right) r\right] \quad$ will be set by supply = demand for non-taxable debt $X^{N T}=\int_{\tau^{*}}^{1} X_{\tau} d \tau$. Each high-tax-rate investor buys bonds $B_{\tau}=X_{\tau} / P=X_{\tau}\left(1-\tau^{*}\right) r$, each of which pays a net coupon of $\$ 1$.

The Treasury's overall net interest cost is now the sum of what it pays to non-taxable investors and to taxable investors,

$$
r \int_{\tau=0}^{\tau^{*}}(1-\tau) \frac{\hat{X}_{\tau}}{X} d \tau+\int_{\tau^{*}}^{1}\left(1-\tau^{*}\right) \frac{X_{\tau}}{X} d \tau .
$$

The overall rate (2) could be either higher or lower than with all taxable debt in (1). It seems that interest costs go up, because the right hand term replaces $(1-\tau)$ with $\left(1-\tau^{*}\right)$ in the region $\tau>\tau^{*}$. But the distribution of debt holdings $\hat{X}_{\tau}$ changes. If actual debt holdings were less than capacity $\hat{X}_{\tau}<X_{\tau}$ in this high-tax region of (1), then those investors will buy more debt $\hat{X}_{\tau}=X_{\tau}$ in (2). In that case, then debt holdings $\hat{X}_{\tau}$ must decline in the low-tax, first term of (2) and net interest costs decline.

Thus, if in (1) the taxable debt happened to be in the hands of high-tax-rate investors, so the left hand term of (2) was already zero and quantities held do not change across tax rates, then replacing $1-\tau$ in (1) with $1-\tau^{*}$ in the right hand term of (2) will raise the government's interest costs. This is the case for taxing debt. However, if in (1) the taxable debt happened to be in the hands of low-tax-rate investors, so that $\hat{X}_{\tau}=0$ for $\tau \geq \tau^{*}$, then the Treasury's interest costs will decline on the introduction of tax-free debt. The government will attract all the high-tax-rate investors to participate, shifting holdings from the left-hand term of (2) to its right-hand term.

In sum, introducing tax-free debt can raise the government's interest costs if 1) high-tax investors receive lower after-tax returns on all their outside investment opportunities, and also 2) taxable government debt is already in the hands of high-tax investors. 


\subsubsection{Which view is right?}

Miller (1977) argued that all investors can get the same after-tax alternative return $r$. One can hold stocks that pay most of their returns as capital gains and not realize capital gains, then step up the basis in estates. One can shield investments in tax-deferred strategies, mentioned above, or in real estate, privately held businesses, and other non-market investments.

Few U.S. taxable investors hold long-term Treasury debt. Treasury Bulletin Table OFS-2, excerpted in Table 2, lists $\$ 17$ trillion in debt. $\$ 7$ trillion is held by government accounts, which pay no taxes, leaving $\$ 10$ trillion held by the public. $\$ 5.8$ Trillion - more than half - is held by foreigners. The Federal Reserve Foreign Portfolio Holdings ${ }^{8}$ Table 12 lists that almost all of the debt held by foreigners is $\$ 4.9$ trillion "long-term" debt, of which $\$ 3.6$ trillion is held by "foreign official" investors, largely central banks. Treasury Bulletin Table FD-5 lists only \$6.5 trillion debt greater than one year outstanding at the end of 2013, suggesting that less than $\$ 1.6$ trillion longterm debt is held by any U.S. investor. The rising yield curve means that more taxable interest comes from longer maturity debt, so the fact that long-maturity debt is so overwhelmingly held by foreign non-taxable investors further reduces taxes on interest.

Table 2: Ownership of Treasury Securities. (\$Billions)

\begin{tabular}{r|r} 
Total public debt & 17,352 \\
SOMA and Intragovernmental holdings & 7,205 \\
Total privately held & 10,147 \\
Depository institutions & 321 \\
U.S. savings bonds & 179 \\
Private Pension funds & 492 \\
State and local government pension funds & 203 \\
Insurance companies & 264 \\
Mutual funds & 1,121 \\
State and local governments & 593 \\
Foreign and International & 5,793 \\
Other investors & 1,179
\end{tabular}

Note: Treasury Bulletin Table OFS-2, values for December 2013. ${ }^{1}$ Includes individuals, Government-sponsored enterprises, brokers and dealers, bank personal trusts and estates, corporate and non-corporate businesses, and other investors

Back to Table 2, \$1.1 trillion is held by mutual funds. To the extent that those mutual funds are held by non-profit or tax-exempt entities, or in tax-exempt or deferred accounts, they escape

\footnotetext{
${ }^{8}$ Foreign Portfolio Holdings of U.S. Securities as of June 30, 2013. Department of the Treasury, Federal Reserve Bank of New York, Board of Governors of the Federal Reserve System, April 2014 http://www.treasury.gov/ticdata/Publish/shla2013r.pdf
} 
taxation. Private pension funds are tax favored ${ }^{9}$ if not tax exempt. State and local governments pay no taxes. Savings bond interest can be deferred or eliminated. The $\$ 1.2$ Trillion held by "other investors," represent a mix of tax rates and tax-avoidance strategies.

The Flow of Funds ${ }^{10}$ Table L. 209 p. 99 gives a similar breakdown; of $\$ 12,756$ billion Treasury, agency, and federal mortgage debt held by the public, households hold only $\$ 547$ billion "bills and other Treasury securities." Corporate and non-corporate business hold a tiny $\$ 40$ and $\$ 52$ billion each, and the rest of the world holds $\$ 6$ trillion.

In sum, the majority of Treasury debt is held by investors who are paying low or no tax rates on interest they receive.

The question "How much revenue does the U.S. earn by taxing Treasury debt?" should be answerable from IRS tax return data. I have not found a source that attempts this calculation. The answer is important.

Lowering interest costs is not the beginning and end of optimal taxation. And these models are very simplistic. But the intuition that offering tax-free debt will lower government revenues or subsidize high-income taxpayers is not in general correct, and quite plausibly incorrect.

\section{Indexed debt}

Indexed debt should be perpetual, and pay a coupon equal to $\$ 1$ times the current consumer price index. The March 2015 CPI is 236.119. Indexed debt would thus pay a coupon of $\$ 2.36119$ for each bond, on an annualized basis. If the CPI rises to 250 in 2020, then indexed debt will pay a coupon of $\$ 2.50$. If the CPI declines to 200 , then indexed debt will pay a coupon of $\$ 2.00$.

\subsection{Why?}

TIPS were a great start. But they can be improved. TIPS increase coupons and principal for inflation, but they do not decrease coupons if the CPI falls below its value on their issue date. As a result, TIPS include an inflation option. And new issues contain a different inflation option than old issues. TIPS have a complex tax treatment. Inflation adjustments to principal trigger immediate tax liabilities. Taxation of the inflation adjustment means that TIPS do not fully protect against inflation.

This heterogeneity and complex tax treatment hinders the collection of TIPS into tax-efficient mutual funds, and muddies their use as inflation hedges. TIPS are, partially as a result, illiquid, and not nearly as popular as economists expected.

\footnotetext{
${ }^{9} \mathrm{http}: / /$ www.taxpolicycenter.org/taxtopics/encyclopedia/pensions.cfm

${ }^{10}$ http://www.federalreserve.gov/releases/z1/current/z1.pdf 
In modern portfolio theory, a non-taxable indexed perpetuity is the central riskless asset for long-term investors (Campbell and Viceira 2001, Wachter 2003, Cochrane 2014a). If you invest in a tax-free indexed perpetuity, you can consume a steady amount forever and ignore mark-tomarket price variation. By contrast, there really is no portfolio problem to which 30 years of coupons and a big principal payment are the answer.

Under the gold standard, Victorian perpetuities offered a real payment essentially immune from substantial inflation. At least there is a historical precedent for the popularity of such as security. Barro (1999) argues that indexed perpetuities are the optimal form of debt finance.

Indexed perpetuities should offer the Treasury lower-cost long-term financing than nominal perpetuities. Investors will accept lower interest rates in return for protection from inflation risk. As evidence of lower borrowing costs, the yield curve was downward-sloping or flat in the 19th century, when the gold standard enforced long-run price stability. The Treasury's TIPS and the U.K.'s inflation-indexed yield curves have also typically been flatter or more inverted than the corresponding nominal yield curves. A better security should enhance this phenomenon. Most economic interest rate models produce a downward sloping average real term structure. Since the indexed perpetuity is the riskless long-term asset, long-run investors demand compensation for the greater long-run reinvestment risk of short-term assets. (Campbell, Shiller and Viceira 2009).

In sum, as with all these innovations, offering a simple, liquid, and popular security should allow the Treasury to finance deficits at lower cost, as well as to improve the functioning of financial markets.

TIPS already serve an important monetary policy function: They allow the Federal Reserve to obtain a direct measure of market-based inflation expectations. However, the illiquidity and complex tax treatment of TIPS makes that tea-leaf reading more obscure than it needs to be. The spread between my indexed perpetuities and nominal perpetuities (or strips or swaps based on these securities) would provide a cleaner measure of expected inflation.

\subsection{Objections and extensions}

An indexed perpetuity does not directly provide inflation protection for shorter-horizon returns. For example, suppose an investor wants to save for college tuition in 10 years. That investor wants an inflation-indexed zero-coupon bond, not an indexed perpetuity.

Inflation-indexed perpetuities can and should, be stripped just like nominal perpetuities. This stripping would yield a market in zero-coupon inflation-indexed bonds. These zero-coupon bonds are natural inflation hedges for discrete-horizon returns, and they can be assembled to be inflation hedges for other nominal fixed income instruments. As with nominal perpetuities, it 
seems best for the Treasury to provide the simplest benchmark security and let private intermediaries create more specialized products.

The price index is a tricky issue. The CPI is imperfect. Improvements in its measurement will impact coupon payments. For example, the change from fixed to chain-weighted CPI was an improvement. The treatment of housing costs and quality changes will surely improve. The future will likely include more real-time data, following the example of the MIT Billion Prices Project.11 Yet, as we have seen with Social Security, index improvements may be fought by those who will be paid less as a result.

Second, governments such as Argentina in serious inflations, and with outstanding inflationindexed debt, have been known to meddle with the CPI calculation. Investors might worry about the same issue in the U.S.

Do investors need some stronger legal rights regarding inflation adjustments? Current TIPS simply specify that the holder will be paid based on the CPI as calculated by the Labor Department. Bondholders seem content with the competence and independence of the BLS. However, we don't have a lot of inflation and have not seen big changes in its computation. Since bondholders may sue the Treasury or BLS in the event of any big changes, establishing the form for such debate ahead of time is a worthy thought.

Beyond supply and liquidity effects, my view that inflation-indexed debt will result in lower cost does assume that inflation risk premiums are valued differently by the Treasury and investors, or that the Treasury expects lower inflation than investors expect. Throughout I presume a sober and solvent U. S. government that wishes to produce strong non-inflationary growth. Like any capital levy, offering non-indexed debt and then inflating it away is cheaper. Once.

TIPS include an inflation option, that coupons and principal are not adjusted downward past the value on their date of issue. There is no economic reason for this option. Why should an investor who wants a steady inflation-protected stream desire, and pay for, a security that rises in real value in deflation? The option may have been added as a sweetener to better market the securities. But the option costs money, and makes the security needlessly complex.

\section{Variable-coupon debt}

Long-term debt should include the right of the government to temporarily lower the coupon, without triggering legal default.

${ }^{11}$ http://bpp.mit.edu/usa/ 
One can imagine all sorts of legal or implicit rules for raising and lowering coupons. On balance, I think the following structure will be most useful and suffer the least problems. The debt includes a promise, for example a $\$ 1$ coupon. But the government has the right to suspend or to lower those coupon payments temporarily. The coupon functions like interest payments of noncumulative preferred stock; not of regular debt, where missed coupons trigger default; nor of regular equity, where dividends are freely variable.

The expectation that the government will restore coupons when the temporary exigency has passed will give the debt value during the reduction of coupons. It also allows the government to sell debt in the first place and even to sell additional debt during a coupon suspension.

This feature applies only to long-term debt. The government does not have the legal right to devalue fixed-value debt relative to reserves and currency.

\subsection{Why?}

Variable-coupon perpetuities would allow the Treasury to quickly manage temporary fiscal problems by lowering coupons, without triggering default or inducing inflation.

Both default and inflation incur far-reaching economic damage. A legal default means widespread lawsuits, attempts to seize assets or revenues, or refuse to pay taxes. Even a technical default, such as delayed coupon payments during a debt-ceiling fracas, could seize up the financial system. Imagine how much easier the Greek debt crisis would have been if Greece did not need to roll over any debt, and had the legal authority to cut coupon payments for a while.

This option would be used sparingly. The height of the Civil War might have been one case, as an alternative to greenback inflation. WWII might have been financed with debt whose coupons would start at War's end. Other advanced countries such as the U. K. in the two world wars, have experienced sufficient stress at other times that this feature might have been appropriate.

This is not a provision wisely used for regular countercyclical policy. The U.S. can easily finance the vast majority of cyclical or even war-related deficits by borrowing more, while still paying coupons. This provision is crucial when credit markets may refuse those options.

As with other kinds of debt, the Treasury could test the waters by issuing some variablecoupon debt and then increasing the amount as markets get used to the idea. However, in this case, more is better. If one tenth of the debt has variable coupons, than those coupons must be cut ten times as much to provide the same budget relief. Investors pricing the bonds will know this fact and charge a larger spread. So the spreads of a small test-the-waters issue will not be a good measure of the spreads when most debt is variable-coupon. Furthermore, perpetuities don't naturally mature. Converting perpetuities to variable-coupon status requires the Treasury to repurchase the old ones and issue new ones, an expensive proposition. 


\subsection{Rules, reputations and temptations}

There are many proposals for government debt with variable coupon or principal repayment. The most common are bonds with repayment linked by formula to GDP. Borensztein and Mauro (2004) advocate debt with repayment linked to GDP growth. Kamstra and Shiller (2010) advocate "Trills," bonds whose repayment varies with the level of GDP. Miyajima (2006) offers a longer literature review, history, and pricing analysis. Geddie (2014) covers some recent experience with GDP-linked debt in Greece and Argentina, along with investor's doubts.

A rule can help to assure investors, and commit the government not to needlessly or perpetually lower coupons. Violation of the rule can trigger legal actions, asset seizures, or other formal sanctions in addition to a more visible loss of reputation.

Rules also have disadvantages. Coupons linked to GDP cannot be varied based on a war, a fiscal shock, a financial crisis, bankruptcy of states or their pensions, a sharp commodity-price or terms of trade shock, and so forth. GDP-linked debt would have specified a reduction in coupons in 2008-2009, during a collapse of interest rates, a flight to U.S. debt, and the easiest ability of the Treasury to borrow in memory, precisely the wrong time.

Some GDP-linked debt proposals are designed as a pre-commitment to countercyclical fiscal stimulus, more than devices to avoid unexpected fiscal stress. If that's a good idea, budget rules are just as easy.

One could write more rules, to create a richly complex state-contingent debt, but it seems fairly pointless to try to do so. Corporations do not pay dividends mechanically linked to sales or profit numbers for just these reasons.

Yes, governments will be tempted to lower coupons ex-post. And there will be strong forces resisting that temptation, or pressing for a restoration of coupons in a suspension. First, a large class of voters and otherwise politically influential owners of the debt act as the shareholders of a corporation do, to demand dividend payments and force a change of management if they are unhappy with dividends. From the founding of the Bank of England, through Hamilton's assumption of revolutionary war debt to the present, powerful bondholders help to have debts repaid or not inflated away. Second, any reduction in coupons that is not quickly or predictably reversed will damage the value of the debt and the government's ability to issue new debt. A desire to build up its creditworthiness and maintain the value of its debt will impel the government to pay coupons, and to clearly explain why coupons are suspended and under what contingencies they will be restored.

The temptation to lower coupons is not qualitatively different from the temptation to inflate nominal debt, or the temptation to default explicitly. A government that can issue nominal debt 
and not inflate it away, that can issue foreign currency debt and not default, has already solved the first-order pre-commitment issues needed to issue variable-coupon debt and not immediately lower the coupons.

Coupons could be freely variable, like corporate dividends. But corporations have clearer structures for representing stockholder interests. Bondholders alone do not elect governments. Freely-varying coupons, rather than a promise that is temporarily suspended, would also lead to continual political debate over the level of coupons.

\subsection{Economics and history}

A long economic literature studies the proper way for governments to handle fiscal and economic shocks.

The legal rights of large-country sovereign debt are weaker than those of private debt, since bondholders can't take over the government or place the country in bankruptcy. The huge sovereign debt literature studies the question whether and to what extent reputations alone can substitute for legal and other costs of default. Bulow and Rogoff (1989) argue that reputation alone is not enough for small countries. Eaton and Fernandez (1995) and Aguiar and Amador (2014) are recent reviews. A superficial summary is that reputations may help, but additional pre-commitment mechanisms that help to induce repayment are valuable.

I have alluded to some of these mechanisms, including the political power of bondholders, and the political costs of violating rules and traditions. In my view, these are sufficient to allow discretionary variable coupon debt of the sort I have described to function, for a government that is already able to pre-commit not to default or inflate standard kids of debt. I do not think a legally binding rule linking payments to GDP or other indices is necessary, worth the loss of flexible state-contingency, and worth the costs of litigation over the index.

Lucas and Stokey (1983) present the classic analysis of optimal state-contingent debt payments. Governments could react to fiscal shocks by raising distorting taxes. State-contingent default allows more smoothing of such taxes and hence fewer economic distortions.

Lucas and Stokey's "default" can be interpreted as actual default, as inflation, or as my proposed reduction in coupon payments. The choice between distorting taxes, explicit default, inflation, or variable-coupon debt hinges on costs of the last three, which Lucas and Stokey do not consider.

Long-term debt is already a useful fiscal stabilizer (Cochrane 2001, Debortoli, Nunes, and Yared 2014). When bond investors see trouble ahead, the relative price of long-term debt can fall and give the government some time to solve its problem. If the government has issued only shortterm debt, then either the price level must rise or the government faces a roll-over crisis. 
The fiscal theory of the price level (See Cochrane 2005 for an introduction and references) interprets inflation as a Lucas-Stokey state-contingent default. Shocks to inflation lower the real value of government debt. This adjustment is automatic, not needing government action, and avoids default costs. Nominal debt is like corporate equity. For these features, Sims (2001) argues for nominal debt rather than indexed or foreign-currency debt.

However, inflation is not costless either. Inflation engineers a transfer from private lenders to borrowers, and in the presence of price-stickiness drags down the macroeconomy as well. Schmitt-Grohé and Uribe $(2004,2005)$ argue that even with a small amount of price stickiness, the reduction in distorting taxes produced by implicit state-contingent default via inflation is swamped by the macroeconomic damage of inflation. In their model, the government should react to fiscal shocks by relying more on distorting taxation than by default via inflation. Variablecoupon debt is even better: it allows a state-contingent default with no increase in distorting taxation, inflation, or explicit default costs.

High ex-post costs are, admittedly, useful ex-ante pre-commitments. Tying government default to painful inflation, harming private contracts and the macroeconomy, widens the group of voters who are opposed to inflation and implicit default, and lowers its attractiveness to a government. On the other hand, a desirable government state-contingent default may coincide with desirable private state-contingent defaults. The latter view motivates some current advice for large inflation in the U.S. and Eurozone, to wash away the perceived "overhang" or "balance sheet drag" of large private as well as public debts.

The most salient danger of variable coupon debt, then, is the same as its advantage. It lowers the costs of lowering coupons. A government fearful of the budgetary and economic consequences of formal default will work harder to avoid it. The threat of chaos was important to resolving the last debt-ceiling fracas. My suggested structure of a rare provision to be used in extremis is an attempt to put some significant costs in the way of coupon reductions.

This brief review takes us deep into the questions I avoid in this essay: how to use the tools I advocate; when and under what limitations to lower coupons. By quickly surveying this literature we see the point here, that variable coupon debt, like the other securities I advocate, is a good set of tools. Governments need to then make the harder decisions about when to use the tools.

Historically, the U. K. suspended convertibility of currency and hence government debt into gold during wars. It then restored convertibility at par after the war. The expectation of this restoration buoyed the value of currency and debt during the war, and the restoration gave bondholders confidence to lend in advance and during the next war. This historical experience should give us some comfort that discretionary suspensions and restorations can work. 
However, this policy led to some inflation during the war, followed by sometimes painful disinflation after the war, as in the 1920s. While similar in spirit, suspending coupons on longterm debt rather than suspending the convertibility of short-term debt should help to isolate government finances from inflation and these undesirable macroeconomic consequences.

\section{Swaps}

The Treasury should originate and trade swap contracts between these forms of debt. Swap contracts exchange cash flows without buying and selling bonds, or exchanging any money up front. For example, a fixed-for-floating swap exchanges a fixed amount $y$ per year in exchange for the floating rate paid to $\$ 1$ of fixed-value debt. The quantity $y$ is determined so that no money changes hands up front. Similarly, an inflation swap trades a fixed amount $y$ per year for the $\$ 1 \mathrm{x}$ CPI paid by an indexed perpetuity. Below, I describe a very simple implementation of such swap contracts.

\subsection{Why?}

One of the Treasury's tasks is to manage the maturity structure of government debt. The Treasury balances, among other considerations, its sense of which debt offers the lowest long-run financing cost, the danger to the budget of rising short-term interest rates, and the macroeconomic and financial effects of different maturity structures. Currently, the Treasury manages interest exposure and maturity structure primarily by changes in the maturity of newlyoffered debt. Repurchases are smaller and rarer.

Swap contracts would allow the Treasury to adjust the government's interest rate or inflation exposure quickly. A large fraction of Treasury securities lie in the proverbial sock drawers of long-term investors. Buying and selling a trillion dollars of debt would be difficult. Buying and selling a trillion dollars of swap contract exposure would be much simpler, as much less cash needs to be moved. This is why even very small banks routinely adjust interest exposure via swaps rather than by buying and selling bonds, mortgages, deposits, and so forth.

Most of all, swap contracts will allow the Treasury to separate the liquidity-provision, debt financing, and risk-management functions of the debt. For example, the Treasury could meet a large "money-like" demand for fixed-value floating-rate debt, but swap out the interest-rate risk to the budget with a large fixed-for-floating swap. The money-like demand attaches to the security itself, not to the interest-rate risk exposure, so the swap does not undo the benefits of the floating-rate issue. 


\subsection{Implementation}

Since we will observe the price of fixed-coupon perpetuities in liquid markets, and since the value of floating-rate debt is always $\$ 1$, pricing and reselling Treasury swap contracts can be easy. This fact allows for a simple structure of Treasury swap markets.

Denote the price of perpetuities at time $t$ by $P_{t}$, and denote the floating rate $r_{t}$. The swap counterparty has a Treasury account with holdings of floating-rate fixed-value debt. For each \$1 of notional swap value, the Treasury will pay (or receive) in each time interval $\Delta$ (e.g. $\Delta=1 / 365$ ) an amount

$$
\left(1-P_{t} r_{t}\right) \Delta+\left(P_{t+\Delta}-P_{t}\right)
$$

into the counterparty's holdings of floating-rate, fixed-value debt.

How does this work? A swap that uses floating-rate debt as collateral, marked to market daily, is the same thing as financing the purchase of a fixed-coupon perpetuity at the floating rate. Now, if the Treasury lends you $\$ P_{t}$, and you use it to buy one perpetuity, then the next day you receive a coupon $\$ 1 \times \Delta$, you pay interest $P_{t} r_{t} \Delta$, and the value of your long term bond increases or decreases by $\left(P_{t+\Delta}-P_{t}\right)$. These are exactly the payments specified by my swap contract.

If prices fall, the counterparty starts losing money. At some point, the counterparty will have to top up their holdings of floating-rate debt, which function as collateral to this swap contract. If the counterparty's holdings drop to zero and he or she does not post more floating-rate debt, the contract is canceled.

How is this contract different from a regular swap? The most important difference is the nature of collateral, fixed-value floating-rate debt, i.e. cash. A conventional swap contract would allow the counterparty to post other collateral, so if the counterparty didn't have a lot of (interestpaying) cash, the counterparty could pledge other securities instead.

In my view, the Treasury should not be in the business of taking, evaluating, seizing, and selling collateral. A party who wishes to post such collateral should use that collateral for a loan from a financial institution, and then use the proceeds of the loan to increment their Treasury floating-rate holdings. Or, such a party should enter directly into the secondary swap market with financial institutions.

The remaining differences between this implementation and a standard swap contract are smaller, and enhance the simplicity and liquidity of this contract. If the Treasury were to enter regular swap contracts, then each contract would be different, based on a different initial value of the perpetuity. In this system, there is a single, resellable, instantly cancelable contract which is the same for everyone. 


\subsection{Counterparties}

Who will buy swaps? First of all, the same banks, financial institutions, foreign central banks, insurers, pensions, and others that deal in and hold Treasury debt. The security that is ideal for the Treasury to manage interest rate risk is also ideal for these institutions to manage interest rate risk, or to take on interest rate risk for a price.

What if the counterparties fail? Swaps are collateralized, so that despite the large payments involved, the Treasury's exposure to credit risk is nil. And the Treasury has certain advantages over other derivatives creditors in getting paid on the failure of financial institutions, especially the large dealer banks. Furthermore, the huge Dodd-Frank bureaucracy, and the Fed's regulators and stress-testers, charged with supervising the complex risks undertaken by financial institutions, can surely monitor interest-rate exposure in plain-vanilla Treasury swap transactions.

The market can be broader. Currently, swap transactions are only available to relatively large financial institutions. The very simple structure of Treasury swaps I describe could open up a retail market, as there is no reason for the Treasury to limit participation in these contracts at all. Homeowners concerned about the effect of interest rate increases on their mortgages, or small businesses worried about their rent and leases, could buy swaps on the Treasury website, just as they buy bills and savings bonds.

\section{Concluding comments}

I introduce a set of tools, but I only touch the vast literature recommending how to use these tools. Should the Treasury issue primarily short-term debt, to harvest the term premium, or longterm debt, to insure the Treasury and the price level against fiscal shocks? Greenwood, Hanson, Rudolph, and Summers argue for the former in Chapter 1; I argue (Cochrane, 2001) for the latter. (See also Faraglia, Marcet, Oikonomou, and Scott 2014.) How much debt of each category should Treasury sell? Should the Treasury fix prices instead and let relative quantities follow market demands? How much inflation risk should the Treasury keep or transfer, via indexed debt or swaps? Under what circumstances should the Treasury temporarily reduce coupon payments? How should it change debt quantities, prices, or relative prices in response to macroeconomic, financial, and fiscal events?

These questions span the modern literature on taxation, debt, fiscal and monetary policy and financial structure. This literature does not yet provide widely accepted answers. But that is not a reason not to introduce the tools. We've had simple government debt for over 800 years, and we 
are still discussing its optimal use. Both sides of any use debate would find improved tools useful. And having the tools in hand may spur better thought on how to use them.

Use of all of these tools, and conventional Treasury debt, has simultaneous repercussions for fiscal policy, for monetary policy as it is now broadly construed, for the macroeconomy, for inflation, and for financial market structure and stability. These concerns are currently spread out over many federal agencies and their constituencies. For example, the maturity question affects monetary and fiscal policy. While the Treasury has been issuing long-term debt to take advantage of low rates and to lock in low financing costs, the Federal Reserve has been buying up that debt and issuing short-term debt (reserves) in quantitative easing. In Chapter 1, Greenwood, Hanson, Rudolph, and Summers point out this loggerhead, and advocate a new Fed-Treasury accord over who is in charge of the maturity structure. Similarly, selling more indexed debt exposes the budget to more inflation risk, but may save financing costs and help to lower inflation. I advocate selling more floating-rate debt to engender more financial stability, a concern of the financial stability part of the Fed, SEC, and other agencies. A larger coordination or "accord" will clearly be desirable.

I introduced fixed-value floating-rate, indexed and nominal fixed-coupon perpetuities, taxable and tax-free form, and long-term debt that allows reductions in coupon payments. Not all these securities are necessary. I see no advantage of having both taxable and tax-free debt, so I recommend issuing all debt in tax-free form only. I recommend that all long-term debt contain the legal right to reduce coupon payments. This is a feature that would be used sparingly. But when it's needed, the more debt that can have coupons reduced, the better. I think the U.S. should issue both nominal and indexed debt, however, as that distinction will give better measurement and control of inflation. Nominal debt is also useful buffer, and as corporations issue both debt and equity, so the government should issue both indexed and nominal debt.

In all cases except variable coupon, though, having both versions does little harm, other than to subdivide the debt into somewhat less deep and liquid versions. Likewise, all of these forms of debt can be introduced gradually, and current debt can slowly run off once experience confirms their value.

I advocate tools that allow the U.S. to borrow more and at lower interest rates. A strand of comment warns against this course. The debt is large and our government's ability to pay it off is in question. Innovations that make borrowing easier, in this view, are to be avoided. Similar "starve the beast" arguments have been made that the U. S. should not adopt a more efficient tax system. I note the argument, and hope that our democracy is strong enough to limit its borrowing 
and taxation voluntarily, and not by tying our government to deliberately inefficient tax and debt structures.

As I write in spring 2015, it is a benign moment for U.S. debt. Interest rates are at historic lows, interest rate volatility is low, and inflation is nearly nonexistent. U.S. government debt remains a safe haven. Few outside the regulatory agencies and academia are worrying about financial stability and how much it could be improved by the diffusion of fixed-value run-proof Treasury debt. Hedging inflation risk, hedging interest rate risk, and avoiding the taxation of Treasury interest are not high on the public agenda. These facts are unheralded benefits of a zerorate, zero-inflation configuration. Planning for fiscal shocks in which the U.S. has trouble borrowing or rolling over debt is not high on many agendas either.

But benign times may not last. The Federal Reserve is determined to raise inflation and thereby interest rates and interest rate volatility if it can do so. The long-term debt situation is dire. If history is any guide, new and unexpected challenges will arise.

But the fact that many issues are not pressing makes this moment an ideal one to restructure federal debt. The calm before the storm is a good time to fix the sails. 


\section{References}

Aguiar, Mark, and Manuel Amador. 2014. “Sovereign Debt.” In Helpman, Elhanan , Kenneth Rogoff and Gita Gopinath Eds., Handbook Of International Economics Vol 4. Elsevier.

Atkeson, Andrew, V. V. Chari, and Patrick Kehoe. 1999. “Taxing Capital Income: A Bad Idea.”

Federal Reserve Bank of Minneapolis Quarterly Review 23, 3-17.

https://www.minneapolisfed.org/research/qr/qr2331.pdf

Barro, Robert J., 1999. “Notes on Optimal Debt Management.” Journal of Applied Economics 2, 281289.

Bulow, Jeremy, and Kenneth Rogoff. 1989. "Sovereign Debt: Is to Forgive to Forget?” The American Economic Review 79, 43-50.

Chamley, Christophe. 1986. "Optimal Taxation of Capital Income in General Equilibrium with Infinite Lives." Econometrica 54, 607-22.

Borensztein, Eduardo, and Paolo Mauro. 2004. "The Case for GDP-indexed Bonds." Economic Policy 19, 166-216.

Campbell, John Y., and Luis M. Viceira. 2001. "Who should buy long-term bonds?" American Economic Review 91, 99-127.

Campbell, John Y., Robert J. Shiller and Luis M. Viceira. 2009. “Understanding Inflation- Indexed Bond Markets." Brookings Papers on Economic Activity Spring, 79-120.

http://www.brookings.edu/ /media/projects/bpea/spring\%202009/2009a_bpea_campbel l.pdf

Cochrane, John H. 2001. "Long-Term Debt and Optimal Policy in the Fiscal Theory of the Price Level." Econometrica 69, 69-11.

Cochrane, John H. 2005. "Money as Stock.” Journal of Monetary Economics 52, 501-528.

Cochrane, John H. 2014a. " A Mean-Variance Benchmark for Intertemporal Portfolio Theory.” Journal of Finance 69, 1-49. doi: 10.1111/jofi.12099.

Cochrane, John H. 2014b. "Monetary Policy with Interest on Reserves." Journal of Economic Dynamics \& Control 49, 74-108.

Cochrane, John H. 2014c. "Toward a Run-Free Financial System." In Martin Neil Baily and John B. Taylor, eds. Across the Great Divide: New Perspectives on the Financial Crisis, Hoover Institution Press. p. 197-249.

Debortoli, Davide, Ricardo Nunes, and Pierre Yared. 2014. “Optimal Government Debt Maturity.” Manuscript, Columbia University, 
www0.gsb.columbia.edu/faculty/pyared/papers/maturity.pdf , and NBER Working paper 20632 http://www.nber.org/papers/w20632.

Duffie, Darrell. 1996. “Special Repo Rates.” Journal of Finance 51, 493-526.

Dybvig, Phillip H., and Stephen A. Ross, 1986. “Tax Clienteles and Asset Pricing.” The Journal of Finance 41, 751-762. doi: 10.1111/j.1540-6261.1986.tb04540.x

Eaton, Jonathan, and Raquel Fernandez. 1995. “Sovereign Debt.” In Gene M. Grossman and Kenneth Rogoff, eds. Handbook of International Economics, Volume III. Amsterdam: NorthHolland.

Faraglia, Elisa, Albert Marcet, Rigas Oikonomou, Adrew Scott. 2014. “Government Debt Management: The Long and the Short of It." Manuscript. Barcelona GSE Working Paper Series 799 http://www.iae.csic.es/investigatorsMaterial/a14512130308archivoPdf31122.pdf

Friedman, Milton. 1969. "The Optimum Quantity of Money." In The Optimum Quantity of Money and Other Essays, pages 1-50. Chicago: Aldine.

Geddie, John. 2014. “Investors say GDP bonds won't work." Reuters. http://www.reuters.com/article/2014/02/21/bonds-gdp-linkedidUSL6N0LN10G20140221.

Gorton, Gary B., and Guillermo Ordoñez. 2013. "The Supply and Demand for Safe Assets.” NBER Working Paper No. 18732.

Greenwood, Robin, Samuel G. Hanson, Joshua S. Rudolph, and Lawrence Summers, 2014. “Government Debt Management at the Zero Lower Bound.” Hutchins Center Working Paper No. 5.

Harley, C. K., 1976, “Goschen's Conversion of the National Debt and the Yield on Consols.” The Economic History Review 29,101-106.

Homer, Sidney. 1975,."The Historical Evolution of Today's Bond Market," in Explorations in Economic Research, Volume 2, number 3 National Bureau of Economic Research, http://www.nber.org/chapters/c9226.pdf

Homer, Sidney, and Richard Sylla. 1996. A History of Interest Rates, Third Edition (Revised), Rutgers University Press.

Judd, Kenneth L. 1985. "Redistributive Taxation in a Simple Perfect Foresight Model." Journal of Public Economics 28, 59-83.

Kamstra, Mark J. Robert J. Shiller. 2010. “Trills Instead of T-Bills: It's Time to Replace Part of Government Debt with Shares in GDP." The Economists' Voice 7(3). http://markkamstra.com/papers/Economists-Voice-TrillsInsteadofTBills.pdf. 
Kohn, Meir. 1999. “The Capital Market Before 1600.” Manuscript, Dartmouth University, http://www.dartmouth.edu/ mkohn/Papers/99-06.pdf.

Krishnamurthy, Arvind, and Annette Vissing-Jorgensen. 2012. "The Aggregate Demand for Treasury Debt." Journal of Political Economy 120, 233-267.

Lucas, Robert E. Jr. 2003. “Inflation and Welfare.” Econometrica 68, 247-274.

Lucas, Robert E. Jr., and Nancy L. Stokey, 1983, “Optimal fiscal and monetary policy in an economy without capital." Journal of Monetary Economics 12, 55-93.

Miyajima, Ken. 2006. "How to Evaluate GDP-Linked Warrants: Price and Repayment Capacity." IMF Working Paper No. 06/85, March 1, 2006. https://www.imf.org/external/pubs/ft/wp/2006/wp0685.pdf

Mankiw, N. Gregory, Matthew Weinzierl, and Danny Yagan. 2009. “Optimal Taxation in Theory and Practice." Journal of Economic Perspectives 23, 147-74.

Miller, Merton, 1977. “Debt and Taxes.” Journal of Finance 32, 261-275. DOI: 10.1111/j.15406261.1977.tb03267.x

Potter, Simon, 2015, “Challenges Posed by the Evolution of the Treasury Market," Speech; Federal Reserve Bank of New York, http://newyorkfed.org/newsevents/speeches/2015/pot150413.html

Schmitt-Grohé, Stephanie, and Martìn Uribe. 2004. "Optimal Fiscal and Monetary Policy under Sticky Prices." Journal of Economic Theory 114, 198-230.

Schmitt-Grohé, Stephanie, and Martìn Uribe. 2005. “Optimal Fiscal and Monetary Policy in a Medium-Scale Macroeconomic Model.” in Mark Gertler Kenneth Rogoff, eds., NBER Macroeconomics Annual 2005, Cambridge MA: MIT Press, p. 383-425.

Sims, Christopher. 2001. "Fiscal Consequences for Mexico of Adopting the Dollar" Journal of Money, Credit and Banking 33, 597-616.

Wachter, Jessica. 2003. "Risk Aversion and Allocation to Long-Term Bonds." Journal of Economic Theory 112, 325-333.

Woodford, Michael. 2004. Interest and Prices. Princeton: Princeton University Press. 